Impact-Cell-Mill の Nozzle 扔よび Disk の材料について

早川 功* - 野村 男次*

On the Materials of Nozzle and Disk of Impact-Cell-Mill (ICM)

Isao Hayakawa* and DanjI Nomura*

A study on the durability of nozzle and disk of Impact-Cell-Mill under impact and erosion of strong water jet was undertaken to obtain the following results. Sintered hard alloys and a cermet gave better results than ceramics and stellite did for keeping durability of the disk. Corundum ( $\alpha$-alumina) was the most suitable material to make a disk of ICM. Since the material of the nozzle was not affected by direct impact of water jet, however, materials of less hardness, flextural strength and bond energy of crystallization than corundum, such as sintered hard alloys and a cermet could be practically employed.

(Received Mar. 17, 1978)

酵母などの単細胞生物の破砕装置として，超音波破碑 装置1，ダイノーミル1，リービーセルフラクショネータ 一2,31など種々の装置がある。しかしこれらはいずれる 大型化芯図ることに若干の問題がある。そこで連続的, かつ大量好理を行ないうる経斉的な方法の開発を試み， ICM (Impact-Cell-Mill の略) を開発4,5,11)した。ICM

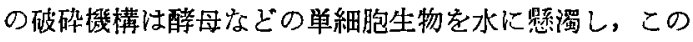

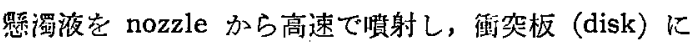

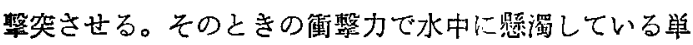
細胞生物を破砕する。

ICM の噴射压力は $600 \sim 1,000 \mathrm{~kg} / \mathrm{cm}^{2}$ で，噴流 (water jet) の平均速度は $400 \mathrm{~m} / \mathrm{s}$ 以上にもなる。こ のことは, disk は勿論, nozzle においても材料の耐侵 食性が ICM の耐久性の面から重要である。ICM の効果 はパン酵母やクロレラなどの破砕に有効であったが，半 面 disk p nozzle の耐久性を損うことが多く, water jet の侵食に強い金属材料が求められた。そこで種々の 材料で試作した disk や nozzle が ICM の water jet に対する耐久性について検討したので報告する。

1. 実験材料わよび方法

（1）供試材料は焼結超硬合金 3 種類, ceramics, cermet, stellite, $\alpha$-alumina (corundum) および各種
表面硬化処理をほどこしたものを用いた。これらのレイ ノルズ数および眯濁夜の宱細については既報参照4,5,12)。

(2) nozzle および disk の耐久試験は ICM にそれら を装着, 噴射圧力 $1,000 \mathrm{~kg} / \mathrm{cm}^{2}$, 間隔 $30 \mathrm{~mm}^{4,5,12)}$ で行 ない，耐久能力は全処理量 (総合計量) で表わし，材料 の耐久性の指標とした。

（3）硬度は Rockwell 硬度計を用い，荷重 $60 \mathrm{~kg}, \mathrm{~A}$ scale で表わした。

(4) 抗折試験は万能引張圧縮試験機を用い，支点間距

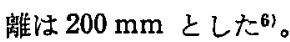

(5) nozzle 口径は顕微鏡測定法を用いた。

(6) イオン結合エネルギーは理論式1)を用いて算出し た。な打電子の荷電は $\mathrm{F} / \mathrm{N}=1.60206 \times 10^{-19}$ coulomb, Madelung constant は交献()より求めた。

\section{2. 結果书よび考察}

（1） disk の材質と而讨久性：ICM の破砕機構は water jet disk に衝突させ，このとき生じる衙慗力を応用 したものである。このときの water jet 流速は $400 \mathrm{~m} / \mathrm{s}$ にも達し，その運動エネルギーは $5.44 \times 10^{2} \mathrm{~kg} / \mathrm{s}$ に至 る。このようなエネルギーが值径 $0.5 \mathrm{~mm}$ 以内の円内に 集中するために，disk の侵食は激しく，一般的なステン レス鋼などでは全く使用に耐えない。次に供試 disk の 耐久試験結果を Table 1 に示し, Table 2 にそれらの 材料特性值および一般成分值を示した。disk の材料は $\alpha$-alumina の単結晶である corundum がもっともすく れており，累計処理量約 $50,000 l$ 後です disk 表面に侵 食は見られず使用可能で，焼結超合金や cermet とより むはるかに耐久性ですぐれていた。またSUS 440 B の 表面焼入法や表画空化処理法などの一般的な表面硬化処

Table 1. Durability of Disks

\begin{tabular}{|c|c|c|}
\hline$\underset{\text { (No.) }}{\text { Sample }}$ & Material. & $\begin{array}{l}\text { ritical operated } \\
\text { volume (liters) }\end{array}$ \\
\hline 1 & Sintered Hard Alloy (A) & $1,500-1,800$ \\
\hline 2 & Sintered Hard Alloy (B) & $2,000-2,500$ \\
\hline 3 & Sintered Hard Alloy (C) & $1,500-1,700$ \\
\hline 4 & Ceramics & 150 \\
\hline $\mathbf{5}$ & Cermet & $2,000-2,500$ \\
\hline 6 & Corundum & Above $\mathbf{5 0 , 0 0 0}$ \\
\hline 7 & Stellite & 800 \\
\hline 8 & $\underset{\text { material }}{\text { Vacuum Plating of (A) }}$ & $0.1-0.2$ \\
\hline 9 & Induction Hardening of $440 \mathrm{~B}$ & 130 \\
\hline 10 & $\begin{array}{l}\text { Chemical Surface Hardening of } \\
440 \mathrm{~B}\end{array}$ & $0.1-0.2$ \\
\hline
\end{tabular}

* 九州大学農学部食糃化学工学科（福岡市東区箱崎） Faculty of Agriculture, Kyushu Univ., Fukuoka-shi, Fukuoka-ken 
Table 2. Physical Properties of Materials and their Components

\begin{tabular}{|c|c|c|c|c|c|c|c|c|c|c|c|c|c|c|c|}
\hline Sample (No.) & $\mathrm{HAR}_{\mathrm{AR}}$ & Flex. & $\mathrm{Ti}$ & C & $\mathrm{TiC}$ & WC & W & $\mathrm{TaC}$ & Mo & Co & $\mathrm{Ni}$ & $\mathrm{Fe}$ & $\mathrm{Cr}$ & $\mathrm{Al}_{2} \mathrm{O}_{3}$ & \\
\hline 1 & 91.5 & 121 & & 6 & & & 89 & & & 5 & & & & & (A) \\
\hline 2 & 91.8 & 215 & & & 5 & 81 & & 5 & & 9 & & & & & (B) \\
\hline 3 & 92.8 & 82 & 25 & 10 & & & 60 & & & 5 & & & & & (C) \\
\hline 4 & 91.3 & 47 & & & & & & & & & & & $\left(\mathrm{Zr} \mathrm{B}_{2}:\right.$ & $: 100 \%)$ & . \\
\hline 5 & 93.1 & 128 & & & 75 & & & & & 5 & 15 & & 5 & & \\
\hline 6 & - & - & & & & & & & & & & & & 100 & \\
\hline 7 & 69.1 & 180 & & 2 & & & 15 & & & $\mathrm{Bal}$ & $<1$ & 0.5 & 28 & & $\mathrm{~V}, \mathrm{Mn}, \mathrm{Ta}<1$ \\
\hline 8 & 92.5 & - & & 0.85 & & & & & 0.5 & & & 80.65 & 18 & & \\
\hline 9 & 69.8 & - & & 0.85 & & & & & 0.5 & & & 80.65 & 18 & & \\
\hline 10 & 57.7 & - & & 0.85 & & & & & 0.5 & & & 80.65 & 18 & & \\
\hline
\end{tabular}

HAR : Hardness of Rockwell A Scale

Flex.: Flexural Strength (kg/square $\mathrm{mm}$ )

Table 3. Durability of Nozzles

\begin{tabular}{clr}
\hline $\begin{array}{c}\text { Sample } \\
\text { (No.) }\end{array}$ & \multicolumn{1}{c}{ Material } & $\begin{array}{c}\text { Critical operated } \\
\text { volume (liters) }\end{array}$ \\
\hline 1 & $\begin{array}{c}\text { Chemical Surface Hardening } \\
(440 \text { B) }\end{array}$ & 200 \\
2 & Induction Hardening (440 B) & 600 \\
3 & Stellite & 4,000 \\
4 & Cermet & Above 20,000 \\
5 & Sintered Hard Alloy (A) & Above 20,000 \\
6 & Sintered Hard Alloy (B) & Above 20,000 \\
7 & Sintered Hard Alloy (C) & Above 20,000 \\
8 & Corundum & Above 50,000 \\
\hline
\end{tabular}

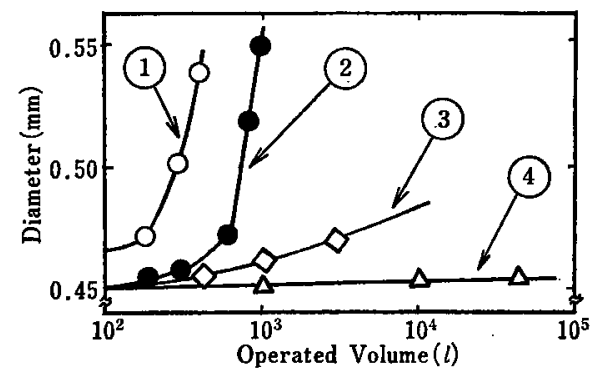

Fig. 1. Relation between operated volume and durability of nozzle

(1): Stainless Steel $440 \mathrm{~B}$ (Chemical Surface Hardening)

(2): Stainless Steel 440B (Induction Hardening)

(3): Stellite

(c): Sintered Hard Alloy (Material: B)

理法は disk の耐久性改善にはつながらなかった。また 抗折力值はコバルトCo の含有率と相対的に関係があ り，Coの增加にともない硬度は低下した。 ceramicsは 高い硬度を示しながらも，耐久性が極端に劣っていた。 その抗折值が極度に低いことから ceramics の分子間結 合エネルギーが弱いるのと思われる。
Table 4. Bond Energy of Crystallization

\begin{tabular}{|c|c|c|}
\hline Materials & $\begin{array}{l}\text { Madelung } \\
\text { Constant }^{\left({ }^{3}\right)}\end{array}$ & $\begin{array}{c}\text { Energy } \\
(\mathrm{K} \text { cal/Mol })\end{array}$ \\
\hline Tungusten (W) & & $210^{9)}$ \\
\hline Iron $\quad(\mathrm{Fe})$ & & $9410)$ \\
\hline Titanium & & $99^{93}$ \\
\hline Tantalum (Ta) & & $180^{9)}$ \\
\hline Molybdenum (Mo) & & $142^{9)}$ \\
\hline Cobalt $\quad(\mathrm{Co})$ & & $85^{9)}$ \\
\hline Magnesium ( $\mathrm{Mg})$ & & $36.3^{10)}$ \\
\hline Aluminum (Al) & & $55^{10)}$ \\
\hline Chromium (Cr) & & $88^{10)}$ \\
\hline Rock Salt $\quad(\mathrm{NaCl})$ & 1.748 & 183.6 \\
\hline Cesium Chloride ( $\mathrm{CsCl}$ ) & 1.763 & 153.2 \\
\hline Rutile $\quad\left(\mathrm{TiO}_{2}\right)$ & 4.816 & 11,070 \\
\hline Corundum $\left(\mathrm{Al}_{2} \mathrm{O}_{3}\right)$ & 25.031 & 35,160 \\
\hline
\end{tabular}

(2) nozzle の材質と耐久性：nozzle の耐久性は disk の耐衙整性と同梯に ICM の耐久性の点で重要な問題で ある。Table 3 と Fig. 1 は nozzle の耐久性を示した。 化学的表面硬化した nozzle (No. 1) は醳母䀣濁液を累 計で約 $200 l$ 処理すると nozzle 内面の硬化材料が消滅 し，440 B の地金が現われ，その後の摩耗が急速に進展 した。高周波焼入 nozzle (No. 2) は化学的表面硬化法 に比較して約 3 倍程度改善されたものの，その值は小さ く，実用には遠いあのであった。Stellite 製 nozzle は 照濁液を累計で約 4,000 l まで処理しえたがなお完全で はなく，とくに nozzle 出口付近での侵食が大きかった。

焼結超硬合金や cermet は disk の場合と異なりそ の耐久性は処理能力の上で累計約 $20,000 l$ 以上耐え得 ることが認められた。Corundum 製 nozzle は累計約 $50,000 l$ 処理後でむ, 外見上の損傷, 摩耗は見られなか った。nozzle は disk と同じ材料で製作されたもので もその耐久性に相違を示した。それは water jet に 


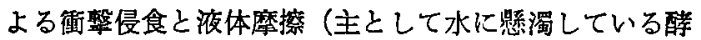
母などの摩擦)の差によって生じているものと思われ た。また耐久性の違いの要因の 1 つ，材料の結合エネ ルギー，または凝集エネルギーの差が考えられるので， イオン結合については理論式》を用い，金属結合につい ては交献から求め Table 4 亿示した。遥移金属はタン グステンでわかるように結合エネルギーは比較的強く， とれらを主成分に用いている超硬合金類が比較的耐久性 にすぐれていたすのと思われる。 $\alpha$-alumina の単結晶 である corumdum は供試材料中もっとも強い結合エネ ルギーを有していたことからも耐久性にすぐれていたこ とが理解できた。

\section{3. 要約}

ICM (Impact-Cell-Mill：衙慗式単細胞破哗機の略) の disk と nozzle の耐久性と金属材料の関係について 実験を行ない次のような結果を得た。

(1) disk の材料は $\alpha$-alumina の単結晶である corundum 以外，全て耐久性に問題を残した。

(2) nozzle の材料は diskの材料よりる，硬度が低く， 分子間凝集エネルギーでも小さなるのでもよく，焼結超 硬合金や cermet 程度以上の硬度や抗折力を有する材料 であるならば全て使用できた。

本研究の一部怊和年 52 度 文 部省科学研究費, 一般
研究Dによって実施したるのである。

$$
\text { 文献 }
$$

1）阿南功一・紺野邦夫・田村善蔵・松橋通生・松本 重一郎編：基礎生化学実験法 I, 丸善, p. 120 (1974).

2) Ribt. E., Perrine. T., List. R., Brown. W., Goode. G.: Proc. Soc. Exptl. Biol. Med., 100, 647 (1959).

3) Hughes. E. D., Wimpenny. T. W.J., Lioyd. D.: "Method in Microbiologg" vol. 5 B, ed. by Norris, J. R. Ribbones, D. W. Academic Press, p. 1 (1971).

4) 早川 功・稲神 馨：食品工誌，19，1 (1972).

5) 早川 功・稲神 熨：食品工誌, 19, 9 (1972).

6）真野克己：標準督械工学実験法, 理工図書, p. 19 (1967).

7）須藤俊男：鉱物化学 II，共立出版， p. 26 (1957).

8）須藤俊男 - 鉱物化学 II, 共立出版, P. 27 (1957).

9）幸田成康：100万人の金属学, 株式会社/フグネ, p. 232 (1965).

10）并口洋夫：物性論入門，共立出版， p. 19 (1968),

11) Hayakawa. I. and Nomura. D.: J. Fac. Agri., Kyushu Univ., 17, 289 (1973).

12）野村男次・早川功 - 篠原和媇：櫭醉工学誌, 52 , 35 (1974).

（昭和 53 年 3 月 17 日受理） 